\title{
The Capitalization of Diversity within the Film Industry
}

\author{
Amir Dhami \\ Halıcıoğlu Data Science Institute, UC San Diego, La Jolla, USA \\ Email: amirdhami@gmail.com
}

How to cite this paper: Dhami, A. (2021). The Capitalization of Diversity within the Film Industry. Sociology Mind, 11, 105-123. https://doi.org/10.4236/sm.2021.113009

Received: June 10, 2021

Accepted: July 24, 2021

Published: July 27, 2021

Copyright $\odot 2021$ by author(s) and Scientific Research Publishing Inc. This work is licensed under the Creative Commons Attribution International License (CC BY 4.0).

http://creativecommons.org/licenses/by/4.0/

\begin{abstract}
Diversity within the film industry is growing in popularity both from a social and economic standpoint. More studios are willing to invest in implementing diversity in film through both the crew and cast. Still, the diversity that is added into film is not always genuine and valued-sometimes it is added for financial incentives. This study aims to determine which genre of film has the least financial incentive for including diversity. The study employs a meta-analysis methodology combined with a survey component. Across the action, drama, horror, and comedy genres, the study will compare quantitative financial metrics against qualitative audience response metrics to answer which genre of film adds valued diversity as opposed to using it as a marketing tool. Within the context of the study, diversity in film is defined as passing two of seven chosen diversity tests, which are acknowledged by multiple publications as legitimate. Data sets of box office revenue, total tickets sold, and dollars spent per ticket are compared to generate a financial perspective. Additionally, data sets of share of voice and a Likert scale survey are compared to generate a general audience perspective. The results of the study yielded the horror genre as having the least financial incentive to include diversity in film. As a result of modern, diverse horror being valued by audiences while spending significantly less on average to market and produce the films, compared to its non-diverse counterpart, a thematic shift within the horror genre may occur within the upcoming decade.
\end{abstract}

\section{Keywords}

Component, Formatting, Style, Styling, Insert

\section{Introduction}

\subsection{Background}

In 2016, The Academy Awards announced its slate of acting nominations for the 
upcoming awards session. Like the years prior, the nominations were exclusively composed of white actors and actresses for all acting categories, consisting of actor in a leading role, actress in a leading role, actor in a supporting role, and actress in a supporting role. Responding with fervent backlash, social media became inundated with the "OscarsSoWhite" hashtag. The hashtag itself was created and semi-popularized by April Reign in January 2015. However, it was not until 2016, when the phrase became the number one trending hashtag on social media platforms such as Twitter (Ugwu, 2020). The hashtag ensured that the spotlight continued to shine on long-existing inequities in the awards recognition-as well as on the larger Hollywood film industry for lacking authentic representation of diverse people (Yousuf, n.d.). Critics of the Academy asserted that nothing would change in the way of recognition as long as its membership-and, hence, the voting body-was still mostly white men. Specifically, Academy voters are approximately $94 \%$ Caucasian and $77 \%$ male, with less than $4 \%$ of the voting population composed of Black and Latino voters (Elist et al., 2012). The argument was that such a homogeneous voting body would always be less inclined to advocate for films that do not represent their experiences-i.e., films that represent the experiences of the marginalized. In response to the backlash from social media, the Academy sought to rectify its internal inequality by recognizing a more diverse pool of actors, actresses, directors, movies, crew, etc. and add more minority voting members; as of 2020, Academy voters are approximately $84 \%$ Caucasian (Stoll, 2021). Studios themselves are committed to financing more diverse films according to Will Packer Productions President, James Lopez (Myers, 2021). However, the diversity present in modern films may be more disingenuous as they stem from financial motivation. Lopez elaborates "It's been proven over and over that diversity sells" and that film studios are not choosing to finance projects with minority cast and crew members because of "altruism... It's a business decision, and you know, at the end of the day, it's all about the green" (Myers, 2021). When the diversity represented in film has ulterior motives from its benefactors, besides pure social consciousness, its implementation is not always truly equal. Disney Pixar's 2020 animated film Onward follows teenage elf brothers Ian and Barley's quest to spend another day with their late father. The feature film received middling to respectable reviews for its plot and animation.

Onward specifically features Disney Pixar's first openly gay character in that of Specter, a lesbian cyclops (Chase, 2020). Although Specter was used in marketing campaigns as being a signal for a change in representation within Disney films, the character appears for only two scenes in the film's domestic release as well as being censored in certain foreign releases (Wiseman, 2020). Films can have diversity but not contain a true representation of said diversity, which is mostly driven by financial motives.

\subsection{Question}

This begs the question: What category of movies has the least financial incentive 
to include diversity? The goal of the research study is to determine which category of film values diversity as opposed to using it as a marketing ploy. It is important for the average filmgoer to know if their money goes to a genre that embraces diversity in the same way they wish the film to.

\section{Literature Review}

In order to gather information from the field of film diversity effectively, only information from credible sources such as the APA, Ebsco, and Google Scholar databases were used. Additionally, all literature used as a reference was published within five years of the 2000s time period, during which the study took place. This ensured that all literature was both credible and relevant to the research study. Additionally, sources that were cited the most by other scholars had a greater weight as a source to further increase the study's credibility as these were the most referenced sources within the field of study. To understand the history and analysis of diversity in film, it is important to examine the existing body of research on the subject. Due to the contemporary nature of diversity in film, a limited assortment of literature exists on the subject. Three studies, specifically, analyze the various perspectives surrounding diversity in film. Joseph E Champoux's (1999) "Seeing and Valuing Diversity in Film" is the most referenced piece of literature in the field of study. The study examines the implementation of workforce diversity theory in film through selected film scenes. Although the paper's findings are far more significant to the teaching of diversity concepts in film schools, the methodology of the study and the analysis of diversity in film has been replicated, to a certain extent, by most other reputable studies in the field of study. Julia Hammett-Jamart's (2004) "Regulating Diversity: Cultural Diversity, National Film Policy and the International Coproduction of Films" takes the metrics for diversity employed in Champoux's study and evaluates the potential of diversity to be expressed in Australian film policy. The study addresses diversity from a cultural and political standpoint. Although it does not address specific sectors of film, it does approach diversity in film from an industry-wide perspective as opposed to Champoux's select film scenes. Finally, Harvey Feigenbaum's (2010) “The Political Economy of Cultural Diversity in Film and Television" scrutinizes the barriers in international trade for diverse film. Connecting back to Disney Pixar's "Onward," foreign markets play an important role in determining which films are employing diversity for monetary reasons. Understanding the regulations of various foreign markets regarding diversity, as covered by the study, plays a key role in establishing metrics to determine financial success and defining diversity in film. With this, there exists a gap in research literature surrounding diversity in film. Including the three most referenced sources in the field of study, all the limited literature examines either diversity in film's inherent importance, historical prominence, cultural impact, or political implications. This study seeks to examine the financial motivations behind implementing diversity in film across various genres and the implica- 
tions of the capitalization of contemporary diversity, while remembering the net positive impact all diversity in film has on society.

\section{Hypothesis}

I would propose that the action genre of film would have the least financial incentive to include diversity. Action, specifically the superhero sub-genre, is the most popular genre of film. With blockbuster films reigning in hundreds of millions to billions of dollars, diversity is not needed to make an action film financially successful nor would it contribute a significant amount to the total gross profit of an action film.

\section{Methodology}

To compare the qualitative sets of data of diversity with the quantitative sets of data that express a film's marketing and financial success, a meta-analysis methodology was employed, combined with a smaller, precise survey component. Additionally, the meta-analysis and survey methodology was employed to compare these perspectives as well-respected literature-Champoux's 2000 study "Seeing and Valuing Diversity through Film" - had done previously, which set precedent for the field of study. Before setting up the specific design of the methodology, it is necessary to define diversity within film, as to attempt to extrapolate quantitative data from a qualitative idea.

\subsection{Diversity}

Because diversity has no official criteria within film, diversity tests that are well-regarded and acknowledged by publications such as The New York Times: "Is Your Script Gender Balanced? Try This Test" (Ryzik, 2018), The Washington Post: "The problem with almost all movies" (Swanson, 2016), The Wall Street Journal: "How the 2016 Oscar Nominees Did on the Bechdel Test" (Feldman, 2016), and many more entertainment magazines, publications, and thought pieces.

The Bechdel Test is derived from Alison Bechdel's 1985 comic strip "The Rule". The comic, although a tongue-in-cheek piece, was widely embraced by reporters and critics in the entertainment industry. Additionally, numerous other tests were created to measure multiple facets of diversity in film. For the purposes of this study, seven diversity tests will be used, each measuring a separate metric of diversity.

- Bechdel

- Representation of women

- Duvernay

- Representation of African-American people

- Maisy

○ Representation in children's movies

- Riz 
○ Representation of Muslim people

- Villalobos

- Representation of Hispanic people

- Vito Russo

○ Representation of the LGBTQ+ community

- Waithe

- Representation of minority women

When determining whether a film is diverse or non-diverse, a film that passes two out of the seven tests will be deemed diverse for the purposes of this study.

\subsection{Financial Success}

Arthouse and major motion blockbusters can both try to showcase representation on the big screen; however, the degree to which they can do so depends on production. The production behind every film differs in budget, quality, management, and other internal factors. The success of a film cannot be measured through only one set metric. Net profit and box office revenue (adjusted for inflation) only show the end success of a movie, ignoring the production cost that went into making it. Ticket sales can show the popularity of a movie but do not accurately compare the success of different generations of films. Inflation and an increase in the total number of movies released each year, as well as many other external factors, make comparing films released in different decades difficult. An easy-to-understand metric of film success is the number of dollars spent by the studio to sell one ticket. This measure is calculated by dividing the production cost of the film (or the production cost plus marketing) by the number of tickets sold. Combining these metrics addresses the issues with reporting each individually. Box office revenue combined with production cost shows the overall financial success of a film, ticket sales show the popularity and outreach of a film, and the dollars spent to sell one ticket show the financial success of a film relative to its budget. For this study, all financial information will be gathered through Box Office Mojo (n.d.).

\subsection{Audience Response}

To determine the level of success of a marketing campaign for a film, whose exact budget is often hidden from the general public, presents a unique intricacy to the study. Metrics not directly tied to the marketing budget of a film such as website traffic, customer retention, and brand awareness have too many factors behind them, which don't always directly correlate to the success of a film. In this study, I will mainly focus on SOV (share of voice), the total percentage of media a company holds within its industry for a given period of time, to illustrate the success of a film's marketing. Since the study examines the specific public response to the film's marketing, placing importance on a film's popularity within the digital media environment compared to its competitors is necessary. Additionally, the study utilizes share of voice to examine a film's impact on 
specific demographics. The share of voice within the study is calculated after the release of the film, not including the buildup leading to the release of the film as to weigh the audience response to the actual film much higher than the audience response to a film's marketing.

Using metrics from both the marketing and financial success of a film, the effect of the implementation of diversity across various genres can be more accurately determined. The two sets of metrics help answer the essential questions behind any film's success-how many people are talking about it and how many people are buying it. Comparing these metrics from different genres to one another should yield a trend that indicates how diversity affects film genres as a whole.

\subsection{Genre Selection and Comparison}

For the sake of clarity and relevance, only the top 4 most financially successful film genres were compared. According to Statista, the top genres of film, by revenue, were Adventure, Action, Drama, and Comedy (Stoll, 2021) (Figure 1). However, many films fall under multiple genres. This causes overlap and allows less-successful genres to piggyback off more successful genres. To remove this overlap, I combined overlapping genres into one, best-fitting genre. Action, Drama, Comedy, and Horror were the genres to be analyzed and compared for the study.

To decide whether a genre valued diversity in films, the top-eight grossing diverse and non-diverse films were compared within each genre. Going further than the top-eight respective grossing films for smaller genres led to too great of a disparity, beyond the point of being comparable, between diverse and non-diverse films. This is a result of diversity only being contemporarily added in film, leading to a much larger breadth of films that are non-diverse. Additionally, due to this necessity for recent films as well as wanting to avoid inflation, which would

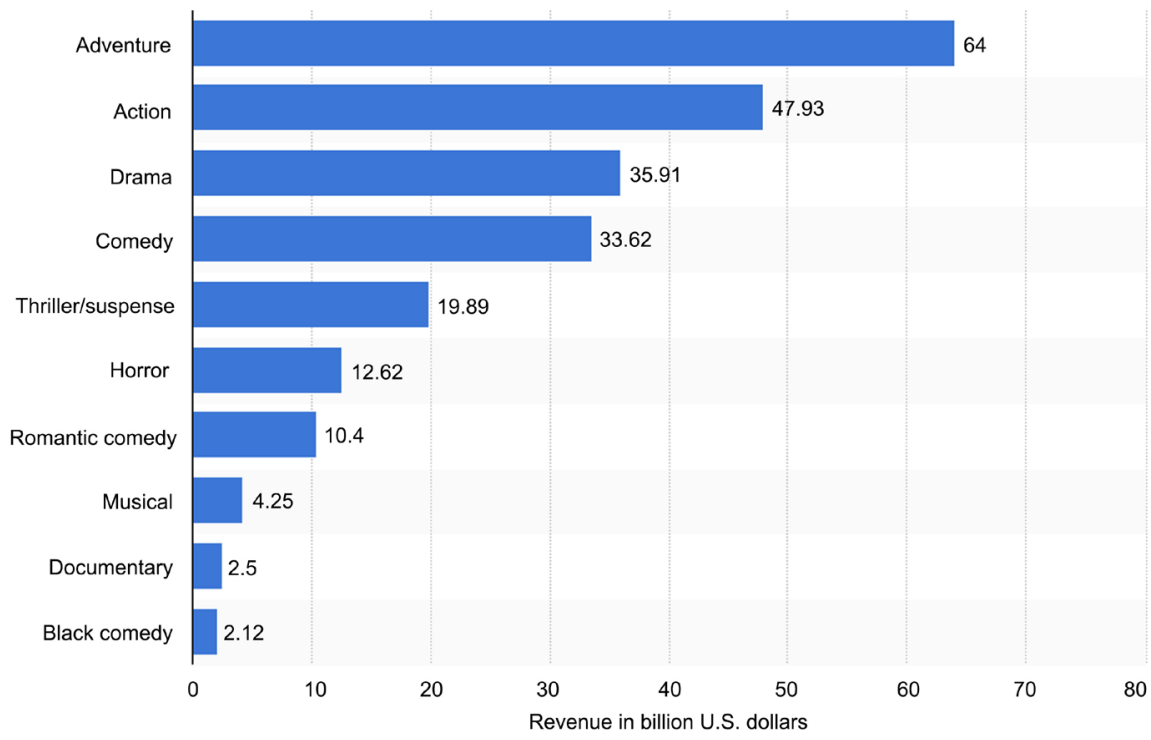

Figure 1. Comparison of the financial success of movies across genres. 
make comparing box office revenue and ticket sales difficult and wanting to avoid the difficulty of comparing older film's media presence, only films released post-2000 will be eligible for the study.

\subsection{Data Collection}

A sample comparison table (Table 1 and Table 2) and equation table (Table 3) are provided on the next pages. The findings were graphed on separate bar graphs, comparing the differences in genre for each metric.

\subsection{Additional Survey Component}

In addition to the primary meta-analysis methodology design of the study, a smaller, secondary survey component was implemented. Diversity will always be a qualitative variable despite the accuracy of the diversity tests. An eye-test of diversity by an average moviegoer serves as a necessary control for the diversity

Table 1. Sample comparison table of films in genre 1 (Diverse).

\begin{tabular}{ccccc}
\hline Film Title & Box office Revenue & Ticket Sales & Dollars Spent per Ticket* & Share of Voice** \\
\hline "Film A" & - & - & - \\
"Film B" & - & - & - \\
"Film C" & - & - & - \\
"Film D" & - & - & - \\
"Film E" & - & - & - \\
"Film F" & - & - & - & \\
"Film G" & - & - & - & $\mathrm{x}$ \\
"Film H" & - & - & $\mathrm{x}$ & \\
Total & $\mathrm{x}$ & $\mathrm{x}$ &
\end{tabular}

Table 2. Sample comparison table of films in genre 1 (non-Diverse).

\begin{tabular}{|c|c|c|c|c|}
\hline Film Title & Box office Revenue & Ticket Sales & Dollars Spent per Ticket* & Share of Voice ${ }^{* *}$ \\
\hline "Film A" & - & - & - & \\
\hline "Film B" & - & - & - & \\
\hline "Film C" & - & - & - & \\
\hline "Film D" & - & - & - & \\
\hline "Film E" & - & - & - & \\
\hline "Film F" & - & - & - & \\
\hline "Film G" & - & - & - & \\
\hline "Film H" & - & - & - & \\
\hline Total & $\mathrm{x}$ & $\mathrm{x}$ & $\mathrm{x}$ & $\mathrm{x}$ \\
\hline
\end{tabular}


Table 3. Equation table.

$\begin{array}{ll}\text { Diverse [Film] } & =\mathrm{D} \\ \text { - A film that has passed at least } 2 / 7 \text { diversity tests } & =\mathrm{G} \\ \text { Gross Profit } & =\mathrm{P} \\ \text { - Profit made before deducting costs } & =\mathrm{G}-\mathrm{P} \\ \begin{array}{l}\text { Production Cost } \\ \text { - Total cost to produce and market a movie }\end{array} & =\mathrm{T} \\ \text { Net Profit } & =\mathrm{P} / \mathrm{T} \\ \text { - Profit made after deducting costs } & \\ \text { Tickets Sold } & \\ \text { - Total tickets sold for a film } & \text { movie's media presence } \\ \begin{array}{l}\text { Dollars Spent per Ticket } \\ \text { - The total cost spent into selling one ticket }\end{array} \\ \begin{array}{l}\text { Share of Voice (as a \%) } \\ \text { - A film's presence compared against competitors through media }\end{array}\end{array}$

tests and a good insight into the niches of diversity in film. Weighing the aggregate conclusion of whether a film is diverse or not from moviegoers against the diversity tests creates a more specific definition of diversity.

To accomplish this, a survey component is implemented that takes inspiration from Champoux's 2000 study. Through a Likert scale, the study more effectively derives further quantitative information from qualitative research to compare against the financial success meta-analysis portion of the study and diversity definition (Watson \& Preedy, 2010) (Table 4).

Two hundred anonymous volunteers were surveyed through IMDb Reviews. I contacted reviewers and asked them to respond to the four questions: How much importance does diversity have in the [action, drama, comedy, horror] film genre on a scale of 1 (least important) to 5 (most important)? The results were graphed on a bell curve for each genre.

In-person interviews, surveys, and focus groups were considered before conducting anonymous surveys; however, a 2012 survey by professors of cognitive science at Cornell University indicated that individuals were more honest when anonymous than in-person when dealing with topics regarding race relations (Ott et al., 2012).

\section{Findings}

\subsection{Data Sets}

The following data tables (Tables 5-12) represent the raw metrics for all financial metrics \& share of voice and an additional table set (Table 13) for the survey component.

\subsection{Financial Comparison}

The gray bars represent the aggregate box office revenue for non-diverse films 
Table 4. Likert scale to compare the importance of diversity in film genres.

\begin{tabular}{cccccc}
\hline Importance & Least & Less & Somewhat & More & Most \\
\hline Rating & 1 & 2 & 3 & 4 & 5 \\
\hline
\end{tabular}

Table 5. Action (Diverse).

\begin{tabular}{ccccc}
\hline Film Title & $\begin{array}{c}\text { Box Office } \\
\text { Revenue }(\$ \mathrm{bn})\end{array}$ & Ticket Sales & $\begin{array}{c}\text { Dollars Spent per } \\
\text { Ticket }(\$)\end{array}$ & Share of Voice \\
\hline Avatar & 2.797 & $147,236,912$ & - & - \\
Star Wars: TFA & 2.068 & $108,866,088$ & - & - \\
Avengers: Infinity War & 2.048 & $107,808,408$ & - & - \\
The Lion King & 1.657 & $87,256,368$ & - & - \\
Furious 7 & 1.515 & $79,750,296$ & - & - \\
Frozen 2 & 1.450 & $76,317,207$ & - & - \\
Black Panther & 1.347 & $70,926,209$ & - & $40 \%$ \\
Harry Potter: DH Part 2 & 1.342 & $78,960,098$ & - & - \\
Total & 14.227 & $757,121,586$ & 2.68 & - \\
\hline
\end{tabular}

Table 6. Action (non-Diverse).

\begin{tabular}{ccccc}
\hline Film Title & $\begin{array}{c}\text { Box Office } \\
\text { Revenue }(\$ \mathrm{bn})\end{array}$ & Ticket Sales & $\begin{array}{c}\text { Dollars Spent per } \\
\text { Ticket }(\$)\end{array}$ & Share of Voice \\
\hline Avengers: Endgame & 2.846 & $149,794,186$ & - & - \\
Jurassic World & 1.670 & $87,921,918$ & - & - \\
The Avengers & 1.518 & $89,342,089$ & - & - \\
Avengers: AoU & 1.402 & $73,832,081$ & - & - \\
Iron Man 3 & 1.214 & $75,925,703$ & - & - \\
Minions & 1.159 & $61,023,403$ & - & - \\
Aquaman & 1.148 & $60,446,626$ & - & $34 \%$ \\
Transformers: DoM & 1.123 & $59,147,057$ & - & - \\
Total & 12.084 & $657,433,064$ & 2.64 & - \\
\hline
\end{tabular}

Table 7. Drama (Diverse).

\begin{tabular}{ccccc}
\hline Film Title & $\begin{array}{c}\text { Box Office } \\
\text { Revenue }(\$ \mathrm{bn})\end{array}$ & Ticket Sales & $\begin{array}{c}\text { Dollars Spent per } \\
\text { Ticket }(\$)\end{array}$ & Share of Voice \\
\hline Bohemian Rhapsody & 0.893 & $45,022,274$ & - & - \\
Ni Hao, Li Huan Ying & 0.835 & $40,963,272$ & - & - \\
Twilight: Breaking 2 & 0.829 & $51,857,796$ & - & - \\
Twilight: Breaking 1 & 0.689 & $47,244,289$ & - & - \\
Life of Pi & 0.619 & $35,430,022$ & - & - \\
Cinderella & 0.534 & $30,444,197$ & - & - \\
Wo he wo de zu guo & 0.465 & $24,495,685$ & - & - \\
Wo bi shi Yao Shen & 0.451 & $22,746,494$ & - & $43 \%$ \\
Total & 5.318 & $298,204,030$ & 2.05 & - \\
\hline
\end{tabular}


Table 8. Drama (non-Diverse).

\begin{tabular}{ccccc}
\hline Film Title & $\begin{array}{c}\text { Box Office } \\
\text { Revenue }(\$ \mathrm{bn})\end{array}$ & Ticket Sales & $\begin{array}{c}\text { Dollars Spent per } \\
\text { Ticket }(\$)\end{array}$ & Share of Voice \\
\hline Twilight: Eclipse & 0.706 & $38,163,307$ & - & - \\
Passion of the Christ & 0.622 & $47,870,280$ & - & - \\
Fifty Shades & 0.570 & $31,041,839$ & - & - \\
American Sniper & 0.547 & $34,207,898$ & - & - \\
The King's Speech & 0.430 & $30,721,411$ & - & - \\
Twilight & 0.402 & $27,142,510$ & - & - \\
Fifty Shades Darker & 0.381 & $22,071,960$ & - & - \\
Fifty Shades Free & 0.371 & $21,578,159$ & - & $30 \%$ \\
Total & 4.032 & $252,797,354$ & 1.95 & - \\
\hline
\end{tabular}

Table 9. Horror (Diverse).

\begin{tabular}{ccccc}
\hline Film Title & $\begin{array}{c}\text { Box Office } \\
\text { Revenue }(\$ b n)\end{array}$ & Ticket Sales & $\begin{array}{c}\text { Dollars Spent per } \\
\text { Ticket }(\$)\end{array}$ & Share of Voice \\
\hline It & 0.701 & $36,899,107$ & - & - \\
I am Legend & 0.585 & $39,035,512$ & - & - \\
It: Chapter 2 & 0.469 & $24,714,042$ & - & - \\
RE: Final Chapter & 0.314 & $16,531,642$ & - & - \\
RE: Afterlife & 0.296 & $18,492,137$ & - & - \\
Split & 0.278 & $14,671,294$ & - & - \\
Get Out & 0.252 & $13,289,481$ & - & - \\
Alien: Covenant & 0.238 & $14,030,662$ & - & $55 \%$ \\
Total & 3.135 & $177,663,877$ & 2.08 & - \\
\hline
\end{tabular}

Table 10. Horror (non-Diverse).

\begin{tabular}{ccccc}
\hline Film Title & $\begin{array}{c}\text { Box Office } \\
\text { Revenue }(\$ \mathrm{bn})\end{array}$ & Ticket Sales & $\begin{array}{c}\text { Dollars Spent per } \\
\text { Ticket }(\$)\end{array}$ & Share of Voice \\
\hline The Nun & 0.363 & $19,125,876$ & - & - \\
Hannibal & 0.350 & $26,930,791$ & - & - \\
A Quiet Place & 0.335 & $17,642,381$ & - & - \\
The Conjuring & 0.317 & $19,862,110$ & - & - \\
The Conjuring 2 & 0.310 & $16,336,831$ & - & - \\
Annabelle: Creation & 0.305 & $16,072,888$ & - & - \\
Annabelle & 0.256 & $16,053,933$ & - & - \\
Halloween & 0.255 & $15,023,358$ & - & $20 \%$ \\
Total & 2.494 & $147,048,167$ & 2.35 & - \\
& & & & - \\
& & & & - \\
\end{tabular}


Table 11. Comedy (Diverse).

\begin{tabular}{ccccc}
\hline Film Title & $\begin{array}{c}\text { Box Office } \\
\text { Revenue }(\$ \mathrm{bn})\end{array}$ & Ticket Sales & $\begin{array}{c}\text { Dollars Spent } \\
\text { per Ticket (\$) }\end{array}$ & Share of Voice \\
\hline Hangover 2 & 0.586 & $34,515,547$ & - & - \\
Les intouchables & 0.484 & $30,303,583$ & - & - \\
Bruce Almighty & 0.484 & $32,297,907$ & - & - \\
Sex and the City & 0.420 & $29,660,518$ & - & - \\
Never Say Die & 0.334 & $17,607,191$ & - & - \\
Feng Kuang De Wai Xing Ren & 0.326 & $17,165,805$ & - & - \\
The Devil Wears Prada & 0.326 & $20,379,572$ & - & - \\
Green Book & 0.320 & $18,825,258$ & - & $49 \%$ \\
Total & 3.278 & $200,755,382$ & 1.54 & - \\
\hline
\end{tabular}

Table 12. Comedy (non-Diverse).

\begin{tabular}{ccccc}
\hline Film Title & $\begin{array}{c}\text { Box Office } \\
\text { Revenue }(\$ \mathrm{bn})\end{array}$ & Ticket Sales & $\begin{array}{c}\text { Dollars Spent } \\
\text { per Ticket (\$) }\end{array}$ & Share of Voice \\
\hline Ted & 0.556 & $32,796,860$ & - & - \\
Meet the Fockers & 0.516 & $32,285,473$ & - & - \\
The Hangover & 0.465 & $27,381,623$ & - & - \\
The Hangover 3 & 0.362 & $19,052,635$ & - & - \\
22 Jump Street & 0.331 & $17,438,625$ & - & - \\
Meet the Parents & 0.330 & $22,028,336$ & - & - \\
Little Fockers & 0.310 & $20,710,038$ & - & - \\
Austin Powers in Goldmember & 0.296 & $24,694,889$ & - & $47 \%$ \\
Total & 3.168 & $196,298,480$ & 1.4 & - \\
\hline
\end{tabular}

Table 13. Importance of diversity per genre survey.

\begin{tabular}{cccc}
\hline Film Genre & Mean & Median & Mode \\
\hline Action & 1.8 & 2 & 2 \\
Drama & 2.7 & 2.5 & 3 \\
Horror & 3.4 & 2.5 & 3 \\
Comedy & 1.3 & 3 & 1 \\
\hline
\end{tabular}

whereas the black bars represent diverse films on a logarithmic scale. Note that all aggregate diverse revenues are greater than their non-diverse counterparts. The average aggregate revenue from greatest to least for diverse films is ordered as follows: action, drama, comedy, and horror. The average aggregate revenue from greatest to least for non-diverse films is ordered as follows: action, drama, comedy, and horror. Comedy has the smallest percentage difference between aggregate non-diverse box office revenue and aggregate diverse revenue, which 
leaves it with the smallest financial incentive. Horror has the largest percentage difference between aggregate non-diverse box office revenue and aggregate diverse revenue, which leaves it with the greatest financial incentive (Figure 2).

The total tickets sold from most to least for diverse films are ordered as follows: action, drama, comedy, and horror. The total tickets sold from most to least for non-diverse films are ordered as follows: action, drama, comedy, and horror. All diverse films within each genre sold a greater number of total tickets than their non-diverse counterparts. Comedy has the smallest percentage difference between non-diverse total tickets sold and diverse total tickets sold, which leaves it with the smallest financial incentive. Horror has the largest percentage difference between non-diverse total tickets sold and diverse total tickets sold, which leaves it with the greatest financial incentive (Figure 3).

The average dollars spent per ticket from greatest to least for diverse films is ordered as follows: action, drama, horror, and comedy. The average dollars spent per ticket from greatest to least for non-diverse films is ordered as follows: action, horror, drama, comedy. Besides horror, all genres spend more money on average to sell one ticket for diverse films than non-diverse films. Action has the smallest percentage difference between non-diverse average dollars spent per ticket and diverse average dollars spent per ticket, which leaves it with the smallest financial incentive. Comedy has the largest percentage difference between non-diverse average dollars spent per ticket and diverse average dollars spent per ticket, which leaves it with the greatest financial incentive (Figure 4).

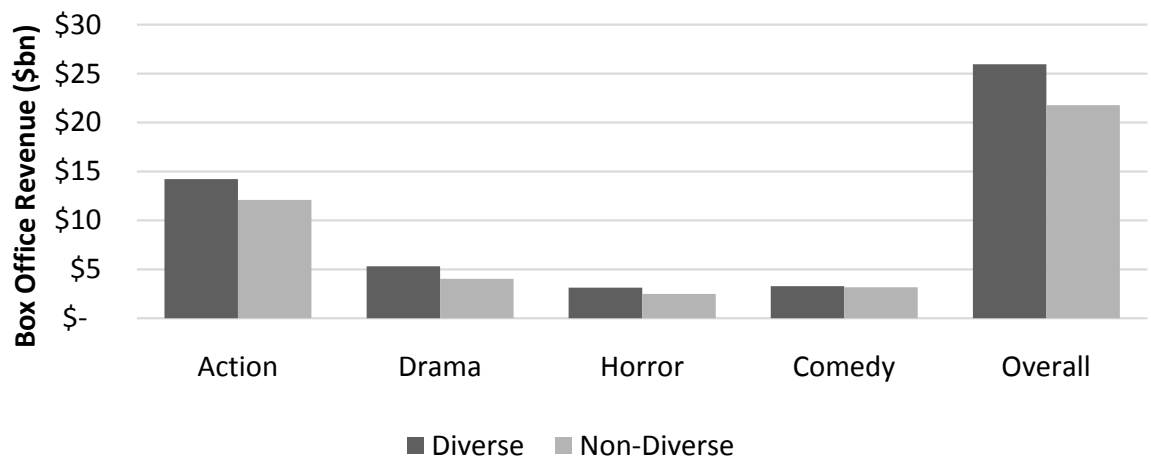

Figure 2. Aggregate box office revenue per genre.

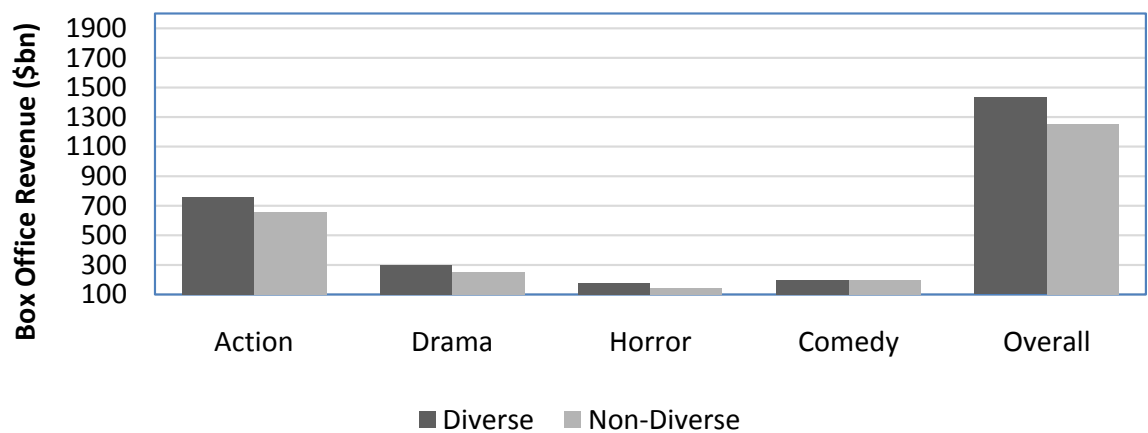

Figure 3. Total tickets sold per genre. 


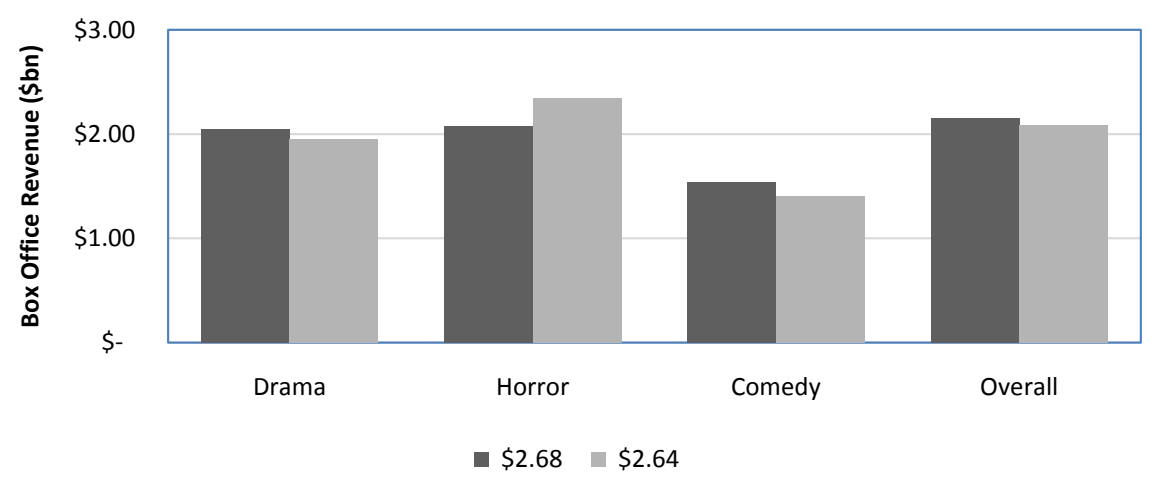

Figure 4. Average dollars spent per ticket per genre.

\subsection{Share of Voice}

The average share of voice from greatest to least for diverse films is ordered as follows: horror, comedy, drama, and action. The average share of voice from greatest to least for non-diverse films is ordered as follows: comedy, action, drama, and horror. For all genres, diverse films on average have a greater share of voice than non-diverse films. As a result, diverse films, on average, are talked about more through social media and traditional media. Comedy has the smallest percentage difference between non-diverse average share of voice and diverse share of voice. Horror has the largest percentage difference between non-diverse average share of voice and diverse average share of voice (Figure 5).

\subsection{Survey}

The mean for the importance of diversity per genre from greatest to least goes as follows: horror, 3.4; drama, 2.7; action, 1.8; and comedy, 1.3. The median for the importance of diversity per genre from greatest to least goes as follows: horror, 3; drama, 2.5; action, 2; and comedy, 1 . The mode for the importance of diversity per genre from greatest to least goes as follows: horror, 3; drama, 3; action, 2; and comedy, 1 . Comedy consistently scores the lowest across all three measures of center, while horror scores the highest (Figure 6).

\section{Results}

\subsection{Financial Success}

Revisiting the research question, the study attempts to determine which genre of film-action, drama, horror, and comedy-has the least financial incentive to include diversity. To answer this, comparing the percentage difference between each genre's diverse and non-diverse films yields each genre's financial incentive to include diversity. Genres with the smallest ratio when dividing the diverse metric by the non-diverse metric will tend to have less of a financial motivation for including diversity. For the aggregate box office revenue, the comedy genre has the least percentage difference and the horror genre has the greatest. Producing a diverse horror film will, on average, yield the greatest percentage increase in box office revenue compared to a non-diverse film. On the other hand, 


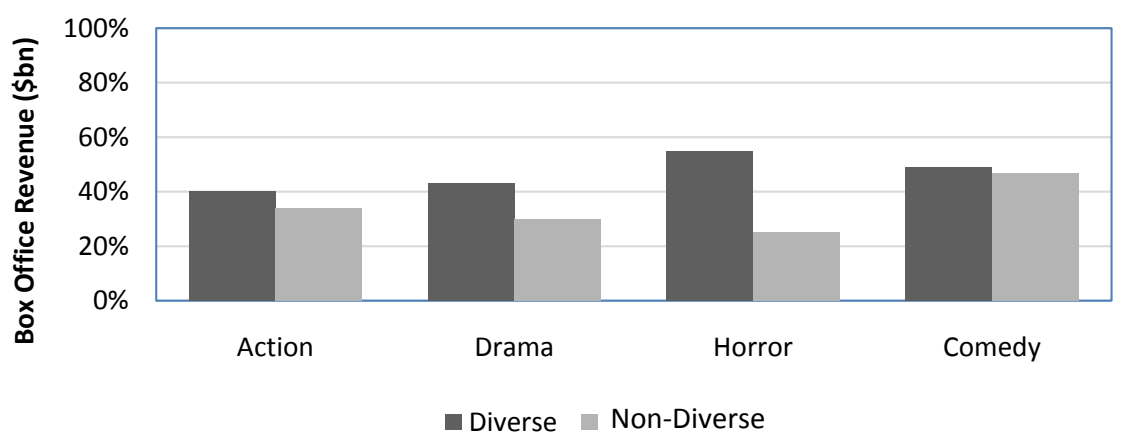

Figure 5. Average share of voice per genre.

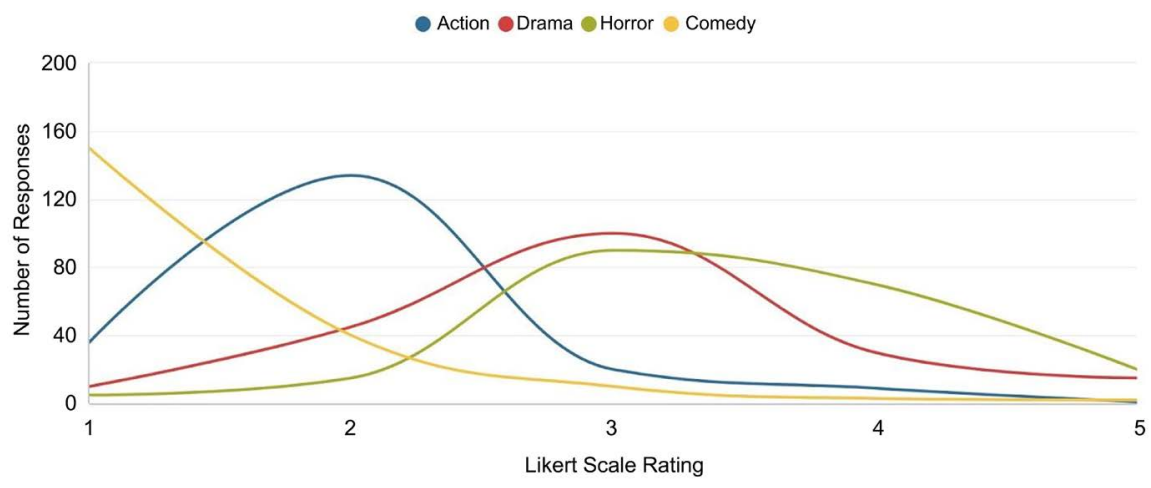

Figure 6. Importance of diversity per genre survey.

producing a diverse comedy film will, on average, yield the smallest percentage increase in box office revenue compared to a non-diverse film. As a result, the horror genre has the greatest financial incentive to include diversity and comedy has the least. Still, this trend needs to be verified across all other financial metrics and survey results.

The total tickets sold assists in balancing the inflation present in box office revenue as well as providing an additional, comparable financial metric. Similar to the box office revenue, comedy, once again, has the smallest percentage difference, while horror has the greatest. Even when accounting for inflation, and shifting the weightage in favor of older films whereas box office revenue shifted it in favor of more recent films, the horror genre has the greatest financial incentive to produce diverse films while the comedy genre has the least incentive.

Average dollars spent per ticket takes into account the production and marketing cost of a film and gives the relative financial success of a film. Sleeper films that became cult-classics, became largely popular with a limited budget, had the greatest weightage in each genre. Comedy has the greatest percentage difference between diverse and non-diverse films. Action has the least percentage difference between diverse and non-diverse films, where the ratio is greater than one. All genres spend more dollars per ticket, on average, on diverse films than non-diverse films besides the horror genre. The production cost and marketing budget for diverse films for all genres besides horror are greater for diverse films than non-diverse films. This leads to the correlation that diverse films 
are marketed more than their non-diverse counterparts.

In the context of diverse films having greater aggregate box office revenues and total tickets sold than non-diverse films, the correlation is logical. Films that spend more on marketing and production will likely be more successful than films that do not. Sleeper films present an outlier to this trend but the general correlation holds true across an aggregate of films.

Still, according to the data, horror films present a continuous outlier to this trend. Although less money is spent on average to produce and market diverse horror films, they perform better in the metrics of box office revenue and total tickets sold than non-diverse horror films. In fact, diverse horror has the greatest percentage difference compared to non-diverse horror for box office revenue and total tickets sold despite being the only genre to spend less to produce and market the horror genre.

\subsection{Audience Success}

For every genre, diverse films held a greater share of voice than their non-diverse counterparts. Films with diversity were consistently mentioned and talked about more on social and traditional media. Comedy had the smallest percentage difference between diverse and non-diverse films at two percent. For the comedy genre, diverse films are discussed almost as much by audiences as non-diverse films. Whether a film is diverse or not does matter as much to general audiences although it has the greatest percentage difference in dollars spent per ticket between diverse and non-diverse comedy films. This correlation likely yields the assumption that little financial incentive exists to market comedy films as diverse due to the little percentage difference in box office revenue, ticket sales, and audience discussion.

The horror genre had the largest percentage difference between diverse and non-diverse films at thirty percent. Although diverse horror spends, on average, less dollars per ticket to market and produce films than non-diverse horror, audiences discuss diverse films more relative to the horror industry than any other genre. Audiences value the thought studios put into expressing diversity through horror films, which leads to the large percentage disparities present in diverse vs non-diverse horror films. A financial incentive does exist to produce diverse horror films but the diversity is greatly valued by audiences. Diverse horror has resulted in multiple films that spend little on marketing but resonate with audiences as seen by the average dollars spent per ticket and share of voice.

This conclusion is supported by the anonymous Likert scale survey that was conducted. Audiences that have reviewed films deemed the diversity present within the horror genre to have the greatest importance due to having the greatest measures of center.

The quantitative financial and direct audience data reflect two conclusions. Although the comedy genre does have the least financial incentive to include diversity in film, the diversity present is rarely appreciated or valued by audiences. Although the horror genre has a compelling financial incentive to include diver- 
sity in film, the diversity present is most appreciated and valued by audiences.

\section{Conclusion}

\subsection{Limitations}

An important limitation of the study is that the only used movies that were created in the 21 st century. If older films were included, far more non-diverse films would dominate each category-seeing how diversity has only recently been valued socially (Bhavnani, 2007). Additionally, an absence of social media presence and deflated ticket prices would make comparing categories more difficult-especially comparing modern, high-grossing action movies to past, cult-classic dramas. Additionally, as previously mentioned, only the top eight highest grossing diverse and non-diverse films for each category could be used. For the drama, horror, and action genres, there was a multitude of diverse and non-diverse films available to be used as a part of the data set. However, the comedy genre had a limited number of diverse films, which led to only the top eight for each category being used. Even with the choice to only include the top eight highest grossing films, the diverse film Green Book is listed as a comedy film. The film which won the Golden Gloves award for Best Comedy or Musical has been criticized for its listing as a comedy film due to the nature of the plot (Lewis, 2019). Although the study follows Box Office Mojo's official categorization as being a comedy film, it is important to acknowledge that the categorization may vary from person to person.

\subsection{Relative Conclusions}

The research question the study is based around is what category of movies has the least financial incentive to include diversity. Examining the financial metrics, the comedy genre has the least financial incentive to include diversity. Audiences do not value the diversity present within the genre so there exists a little financial incentive to include diversity. This conclusion does not align as directly with the goal of the study - to determine which category of film values diversity as opposed to using it as a marketing ploy-as the horror genre. Diverse horror films do have a financial incentive to be produced; however, it maintains the goal of the study. Diversity in the horror genre is not used as a marketing ploy because the production and marketing budgets for diverse films are less on average than non-diverse films according to the average dollars spent per ticket. Additionally, the large difference between diverse and non-diverse horror's share of voice and the high mean with regards to the Likert survey result in audiences valuing diverse horror.

\subsection{Implications}

Affirmative action programs within Hollywood are not necessary because the film industry is already able to implement financially successful diversity under public scrutiny. Diversity tests such as Bechdel, Duvernay, Maisy, Riz, Villalo- 
bos, Vito Russo, and Waithe are widely used by the public through social media and publications to ensure that studios represent minority groups. Continued public scrutiny serves as an external critique of film diversity. Industry review through affirmative action programs is unnecessary because non-diverse films are criticized by the public and as a result, poorly received.

Overall, diverse films spend more on average to sell a ticket than non-diverse films. This means that the production cost relative to the success of the film for diverse films is already, on average, greater than non-diverse films. Affirmative action programs are unnecessary because studios understand that diverse films offer a greater ROI than non-diverse films. There is already a financial incentive to include diversity so an affirmative action program would not be effective.

All diverse genres sold more tickets in total as well as had a greater aggregate box office revenue than their non-diverse counterparts. Diverse films are more financially successful at the box office than non-diverse films. Not only do diverse films have a greater ROI than non-diverse films, but they also generate more revenue, on average. Affirmative action programs would do little to increase the success that diversity already sees in the film industry.

In addressing the goal of the research, horror is the genre that most values diversity in the film while not only using it as a marketing ploy. It stands to reason that if well-done diverse horror can find consistently greater financial success than non-diverse horror, the genre is due for a thematic shift. Psychological horror films, which contain the most valued representation, on average spend less on marketing than their non-representative counterparts while being talked about by audiences more and having greater financial success. This indicates that the horror genre, which has had thematic shifts in the past-from monster movies to slashers to gore-is more financially successful and diverse through the original psychological sub-genre than the current popularity of remakes, reboots, and sequels of past horror films (Zillmann \& Gibson, 1996). As a result, former, smaller studios that exclusively produce modern, diverse psychological horror such as Blumhouse and A24 may be edged out of the industry as they likely will have to compete with the upcoming capitalization of the genre. Moving away from the classic gore and slasher films to modern, diverse, psychological horror like Get Out, Us, Split, Midsommar, and Hereditary is a trendy thematic shift that studios should look to capitalize on in the upcoming decade.

\section{Conflicts of Interest}

The author declares no conflicts of interest regarding the publication of this paper.

\section{References}

Bhavnani, R. (2007). Barriers to Diversity in Film (p. 205). UK Film Council.

Box Office Mojo. (n.d.). https://www.boxofficemojo.com/

Champoux, J. E. (1999). Seeing and Valuing Diversity through Film. Educational Media 
International, 36, 310-316. https://doi.org/10.1080/0952398990360410

Chase, S. (2020, February 21). Onward Features Disney Pixar's First LGBTQ+ Character. Digital Spy. https://www.digitalspy.com/movies/a31048375/disney-pixar-onward-lgbtq-character-o fficer-specter/

Elist, J., Vankin, D., Johnson, R., \& Rome, E. (2012, February 19). Unmasking Oscar: Academy Voters Are Overwhelmingly White and Male. Los Angeles Times. https://www.latimes.com/entertainment/la-et-unmasking-oscar-academy-project-2012 0219-story.html

Feigenbaum, H. (2010). The Political Economy of Cultural Diversity in Film and Television. In J. P. Singh (Ed.), International Cultural Policies and Power (pp. 77-83). Palgrave Macmillan. https://doi.org/10.1057/9780230278011 7

Feldman, L. (2016, January 14). How the 2016 Oscar Nominees Did on the Bechdel Test. Wall Street Journal. https://www.wsj.com/articles/not-in-the-picture-1452807110

Hammett-Jamart, J. (2004). Regulating Diversity: Cultural Diversity, National Film Policy and the International Coproduction of Films. Media International Australia, 111, 46-62. https://doi.org/10.1177\%2F1329878X0411100107

Lewis, H. (2019, January 6). Golden Globes: Peter Farrelly Praises “Hope” of 'Green Book' in Best Motion Picture, Comedy or Musical Win. The Hollywood Reporter.

https://www.hollywoodreporter.com/movies/movie-news/green-book-wins-golden-glo be-best-motion-picture-comedy-musical-1173950/

Myers, K. (2021, February 19). 'Studios Will Keep Financing’ Black, Brown Films Because 'Diversity Sells,' Says Producer. Yahoo!Finance.

https://finance.yahoo.com/news/studios-will-keep-financing-black-brown-films-becau se-diversity-sells-says-will-packer-productions-president-171327511.html

Ott, M., Cardie, C., \& Hancock, J. (2012). Estimating the Prevalence of Deception in Online Review Communities. Proceedings of the 21st International Conference on World Wide Web, Lyon, 16-20 April 2012, 201-210. https://doi.org/10.1145/2187836.2187864

Ryzik, M. (2018, May 11). Is Your Script Gender-Balanced? Try This Test. The New York Times.

https://www.nytimes.com/2018/05/11/movies/is-your-script-gender-balanced-try-thistest.html

Stoll, J. (2021, January 13). Distribution of Voters at the Academy Awards in 2020, by Ethnicity. Statista.

https://www.statista.com/statistics/321291/voters-academy-awards-ethnicity/

Swanson, A. (2016, April 12). The Problem with Almost All Movies. Washington Post. https://www.washingtonpost.com/news/wonk/wp/2016/04/12/the-problem-with-almos t-all-movies/

Ugwu, R. (2020, February 6). The Hashtag That Changed the Oscars: An Oral History. The New York Times.

https://www.nytimes.com/2020/02/06/movies/oscarssowhite-history.html

Watson, R., \& Preedy, V. (2010). 5-Point Likert Scale. In V. R. Preedy, \& R. R. Watson (Eds.), Handbook of Disease Burdens and Quality of Life Measures (p. 4288). Springer. https://doi.org/10.1007/978-0-387-78665-0 6363

https://link.springer.com/referenceworkentry/10.1007\%2F978-0-387-78665-0 6363\#cit eas

Wiseman, A. (2020, March 6). Disney/Pixar's 'Onward' Banned in Multiple Middle East Countries Due To Lesbian Reference. Deadline.

https://deadline.com/2020/03/disney-onward-banned-multiple-middle-east-markets-le 
$\underline{\text { sbian-lgbt-reference-1202876168/ }}$

Yousuf, I. (n.d.). What Is the Significance of the \#OscarsSoWhite Hashtag? Encyclopedia Britannica.

https://www.britannica.com/story/what-is-the-significance-of-the-oscarssowhite-hasht ag

Zillmann, D., \& Gibson, R. (1996). Evolution of the Horror Genre. In J. B. Weaver, \& R. C. Tamborini (Eds.), Horror Films: Current Research on Audience Preferences and Reactions (pp. 63-80). Erlbaum. 